\title{
Review of The Life of Cheese: Crafting Food and Value in America by Heather Paxson
}

\author{
Jon D Holtzman
}

\author{
Book details \\ Heather Paxson \\ The Life of Cheese: Crafting Food and Value in America \\ Berkeley, University of California Press; 2012 \\ 283 pages \\ ISBN: 9780520270183
}

\section{Book review}

The Life of Cheese is an engaging ethnography, focusing principally on varied issues involving American producers of artisanal cheese. Heather Paxson, an accomplished anthropologist as well as a lover of fine cheese, centers her lively ethnography and analysis on cheesemakers (rather than consumers or the cheese itself), focusing on such issues as how artisanal cheesemakers became involved in the craft and lifestyle, how the craft has emerged within broader trends in American farming and food systems, and how it is situated within broader historical and political economic forces. One of the most important orienting themes throughout is Paxson's focus on artisanal cheese as an "unfinished commodity." That is, artisanal cheese is not a uniform product severed from those who produced it, but a food that's value is always derived from its rhetorically constructed residual connections to the cheesemaker. In this sense, what is being produced is never merely the cheese itself, but the story behind the cheese - the passion of the cheesemakers for their craft, the beautiful landscapes in which it is produced, the allure of the hand-crafted in an industrialized society and similar motifs. Paxson, thus, details the values, strategies and contradictions that are immanent in a life oriented on making and marketing something that is in a material sense mere lumps of curdled milk solids at the same time that it contains - to the

Correspondence: jon.holtzman@wmich.edu

Department of Anthropology, Western Michigan University, 1903 W

Michigan Ave, Kalamazoo, MI 49008-5306, USA makers and consumers - the headiest dreams of a better, simpler relationship to food and the earth.

The characters that are assembled in this world of artisanal cheesemaking are varied and complex. They range from very wealthy heirs and second careerists to struggling dairy farmers trying to find ways to add value to their products, from award winning cheesemakers aiming to find ways to bring the best cheesemaking practices to the American scene to people who seem to be essentially well-heeled hobbyists. Paxson is well aware of the tensions inherent in many of the issues she explores, though I am unsure that anyone is nimble enough to explore them fully particularly while remaining sensitive to the cheesemakers who have made this book possible by sharing with her their lives and their craft. One example of this is the issue of class, found in several ways in the book's focus on a luxury product produced as the outgrowth of what is in many instances a luxury lifestyle. Paxson tends to offer countervailing examples regarding class, rather than attempting to resolve the inherent tensions. Thus, for instance, she shows us that although perhaps a quarter of her artisans entered the craft as quite rich people, many others are struggling, working insanely long hours just to try to make ends meet. This is an important observation, though it more elides than illuminates class issues in food generally, or artisanal cheese in particular. One particularly striking example of this came in a cheesemaker's criticism of his farm's previous owner. While this cheesemaker feels the previous owner abused the land and his animals through 
industrial farming methods he does not seem to be cognizant that such methods may be a necessary response to the economic struggles of trying to run an economically viable farm when you do not, like him, have additional income from a software career to draw from. Similarly, Paxson engages with the fact that irrespective of the rhetoric embedded in artisanal cheesemaking, food systems and the world are not going to be saved through $\$ 30 /$ pound cheese. To this Paxson turns to a concept borrowed from Sidney Mintz, "food at moderate speeds," produced through "better" methods but using more economy of scale than might be advocated by "Slow Food" activists in order to make such foods accessible to a broader swath of consumers. This is a worthy goal and Paxson's exploration of it is very worthwhile, though I was left wondering whether \$15/pound cheese gets one much closer to making this vision than the $\$ 30$ / pound stuff. I don't know whether issues such as these are fully resolvable, nor whether Paxson could have dealt with them in a more head-on way while remaining sensitive to her subjects, but readers should be attuned to these tensions. Through both her ethnography and engaging analysis, Paxson offers much for readers to consider.

In another sense, the book, like many in the food studies genre, is situated in an awkward, if worthwhile, place, being rigorously scholarly while aiming to appeal to an educated non-expert audience. This approach is on one hand very positive through its aim of bringing top-notch scholarship to a broader audience. At the same time, however, it also risks ghettoizing food studies to the proverbial cheese cavern, trafficking in familiar Euroamerican tropes that can be readily digested by fine foodies, rather than expanding the theoretical horizons of food - arguably both the most primal and intricate arena of human life. Paxson's complex and well-argued book does not much suffer from this trap, but there is awkwardness in aiming to successfully balance two somewhat countervailing needs. To cite an obvious example, early in the book Paxson defines "participant observation" for readers who never took Anthropology 101, while later expressing her ideas through conceptual density that is unlikely to be accessible to all interested readers. That said, this speaks more to the question of how, not if, readers should approach this excellent book, which is able to speak to a fairly diverse audience if not always at the same time. There is much here for those concerned with sustainable food systems, those who simply have a strong interest in cheese, and for those most focused on its serious engagement with food scholarship. This book should have strong appeal to all of these groups.
Competing interests

The author declares that he has no competing interests.

Received: 4 December 2012 Accepted: 10 December 2012 Published: 4 March 2013

doi:10.1186/2044-7248-2-15

Cite this article as: Holtzman: Review of The Life of Cheese: Crafting Food and Value in America by Heather Paxson. Flavour 2013 2:15.

\section{Submit your next manuscript to BioMed Central and take full advantage of:}

- Convenient online submission

- Thorough peer review

- No space constraints or color figure charges

- Immediate publication on acceptance

- Inclusion in PubMed, CAS, Scopus and Google Scholar

- Research which is freely available for redistribution 